Boston University School of Law Scholarly Commons at Boston University School of Law

Faculty Scholarship

Fall 9-12-2017

\title{
Understanding the Failure of Health-Care Exceptionalism in the Supreme Court's Obamacare Decision
}

Abigail Moncrieff

Boston University School of Law

Follow this and additional works at: https://scholarship.law.bu.edu/faculty_scholarship

Part of the Health Law and Policy Commons

\section{Recommended Citation}

Abigail Moncrieff, Understanding the Failure of Health-Care Exceptionalism in the Supreme Court's Obamacare Decision, 142 Chest 559 (2017).

Available at: https://scholarship.law.bu.edu/faculty_scholarship/117 


\title{
Understanding the Failure of Health-Care Exceptionalism in the Supreme Court's Obamacare Decision
}

\author{
Abigail R. Moncrieff, JD \\ Peter Paul Career Development Professor \\ Associate Professor of Law \\ Boston University School of Law
}

Address Correspondence to:

\author{
Abigail R. Moncrieff \\ Boston University School of Law \\ 765 Commonwealth Ave. \#1170D \\ Boston, MA 02215 \\ Email: arm11@bu.edu
}

Word Count: 2405

Author contributed to two amicus briefs filed before the Supreme Court in support of the constitutionality of the individual mandate. She reports no other conflicts of interest relevant to this manuscript. 


\begin{abstract}
:
On June 28, 2012, a mere century after the first presidential proposal for national health insurance, the Supreme Court issued a resounding victory for President Obama and for health-care reform generally, upholding the Patient Protection and Affordable Care Act against a serious constitutional challenge. Nevertheless, the Court also struck a potential blow to future health-care reform efforts. A majority of the Court refused to accept the Solicitor General's argument that health care is a unique market with unique regulatory needs that justify special constitutional treatment. The failure of health-care exceptionalism in the Court's opinion might render future reform efforts more difficult than they would have been if the Solicitor General's argument had carried the day. This Commentary seeks to shed light on the Court's hesitation to recognize the uniqueness of health insurance and health care, noting that market-based exceptionalism in constitutional law has a long, dark history that the Court was understandably loath to repeat. Although the result of the majority's one-size-fits-all approach to constitutional analysis in this case is an odd holding that elides some genuine uniqueness of American health care, the alternative of health-care exceptionalism might have been much worse for our overall constitutional system.
\end{abstract}


Understanding the Failure of Health-Care Exceptionalism in the Supreme Court's Obamacare Decision

On June 28, 2012, the Supreme Court issued a resounding victory for President Obama and, perhaps even more so, for national health care reform. After nearly 100 years of presidential campaigning for universal health care, starting with Theodore Roosevelt's reelection bid on the Bull Moose ticket in 1912, Congress finally managed to pass comprehensive reform. ${ }^{1}$ And now the Supreme Court has upheld the resulting statute, the Patient Protection and Affordable Care Act (ACA), against what had become a serious constitutional challenge. A full century after Roosevelt's campaign, comprehensive national health care is a reality in the United States.

But in an important sense, both President Obama and national health care reform also suffered a defeat in the Supreme Court's opinion. Chief Justice John Roberts, who authored the majority opinion, flatly refused to grant the Obama Administration's request for health-care exceptionalism in constitutional law. Throughout the written briefs and oral arguments, the government argued that health insurance and health care are unique markets that Congress should be allowed to regulate in unique ways.

Roberts wasn't having it. In two pages of his opinion, Roberts denied that health insurance is unique and refused to create an exception to the general rule that Congress may not force people to buy things. ${ }^{2}$ Furthermore, in upholding the individual mandate under Congress's taxing power, Roberts treated the mandate as an ordinary incentive for private consumption of goods, ${ }^{2}$ failing to identify another interesting argument that used to exist in American constitutional law: that a health insurance pool is extremely similar to a tax pool, such that a requirement to buy health insurance is no different from a requirement to pay taxes. 3

In short, Roberts treated the individual mandate as a generic effort to get people to buy something. It was totally irrelevant to his analysis that the "something" in this case was health insurance.

So why is the failure of health-care exceptionalism a defeat for health-care reform, and why did Roberts insist on denying that health insurance is unique? On the first, the answer is that health care stood a chance of gaining special constitutional status that could have made future health-care reforms easier to pass. The government was asking for extra latitude when regulating the healthcare market, and the Supreme Court refused to grant it. For those who believe that the ACA falls short of truly rationalizing American health care, this defeat may prove dramatic. Americans might be in for another 100-year slog. But the answer to the second question ought to provide some comfort for those who, despite wanting a rational health-care system, also want a strong constitutional system. Roberts's one-size-fits-all approach to the ACA's constitutionality will save future Supreme Court justices from going down the rabbit hole of asking why the uniqueness of health insurance mattered and whether the uniqueness of some other market ought to matter, too. Importantly, the Supreme Court used to engage in market-specific analysis of commercial regulation, asking whether a given 
market was so "impressed with a public interest" that its rates could be freely regulated, ${ }^{4}$ and the result was a colossal mess. By rejecting health-care exceptionalism here, Roberts avoided repeating that history.

\section{The Failure of Health-Care Exceptionalism under the Commerce Clause}

Throughout the ACA litigation, President Obama's legal team cast the individual mandate as a one-time-only attempt to correct a unique problem: the $\$ 43$ billion per year problem of uncompensated medical bills and the cost shifting that results therefrom. ${ }^{5}$ A health insurance mandate is not like a broccoli mandate, the Solicitor General argued, because everyone consumes health care, no one can predict how much they will consume this year, and insurance is merely the means of financing the commercial activity that is inevitably coming. ${ }^{6}$ The Supreme Court need not have worried, according to Obama's team, that upholding the individual mandate would allow Congress to impose other kinds of mandates because the health insurance mandate does not force people to buy something they otherwise wouldn't. It merely requires people to pay for something they inevitably consume. A decision upholding the individual mandate under the Commerce Clause would be a one-time-only constitutional allowance for a truly unique market, not a scary expansion of federal power.

Notably, the Obama Administration's argument missed the many unique ways that third-party health insurers regulate the consumption choices of their patients (a point I made at length in a prior commentary for $\mathrm{Chest}^{7}$ ). Health insurance is not just a means of paying for inevitable health-care consumption; it is also a means of steering patients' consumption choices. Third-party health insurance (unlike standard kinds of indemnity insurance like car and homeowners insurance) manipulates patients' perceived costs in order to encourage consumption of preventive care, primary care, and generic pharmaceuticals, and it actively discourages consumption of unnecessary care by refusing coverage based on medical necessity review. Ordinary indemnity insurance doesn't do those things. As I argued before, these truly unique features of health insurance should have made the constitutional analysis easier under the Commerce Clause. ${ }^{7}$ Nevertheless, these arguments would not have avoided health-care exceptionalism. An opinion holding that a health insurance mandate is a constitutionally permissible means of regulating health-care consumption would have rested either on an argument that health insurance is uniquely regulatory or on a holding that purchase mandates generally are permissible means of improving markets' efficiency (a holding that five Supreme Court justices wanted to avoid and that the Solicitor General, probably aware of the justices' resistance, did not request).

In the end, though, the Solicitor General's failure to raise these morecompellingly-unique features of health insurance might have been harmless. Chief Justice Roberts seemed entirely disinclined to accept health-care exceptionalism as a justification for the mandate's constitutionality. Indeed, he argued emphatically that the interrelationship between health insurance and health care should be irrelevant to the Commerce Clause analysis: 
No matter how "inherently integrated" health insurance and health care consumption may be, they are not the same thing: They involve different transactions, entered into at different times, with different providers. And for most of those targeted by the mandate, significant health care needs will be years, or even decades, away. The proximity and degree of connection between the mandate and the subsequent commercial activity is too lacking to justify an exception of the sort urged by the Government. The individual mandate forces individuals into commerce precisely because they elected to refrain from commercial activity. Such a law cannot be sustained under a clause authorizing Congress to "regulate Commerce."

The Possibility of Insurance Exceptionalism under the Taxing Power

In analyzing and upholding the individual mandate under the taxing power, Chief Justice Roberts once again treated the mandate as an ordinary purchase incentive, with no acknowledgement that health insurance might be different from other marketable goods and services. Indeed, Roberts analogized the individual mandate to tax penalties for purchasing cigarettes, marijuana, and sawed-off shotguns, ${ }^{8}$ as well as analogizing it to tax incentives for purchasing homes and professional educations. ${ }^{9}$ Of course, under modern tax analysis, there was no need for health-care exceptionalism. Congress uses tax incentives all the time to steer consumption and to spur commerce. That Congress applied this ordinary and unproblematic approach to health insurance is and ought to be irrelevant.

Nevertheless, there is an outdated Supreme Court case that could have allowed a market-specific approach to the tax analysis here, and that case helps to explain the failure of health-care exceptionalism under the Commerce Clause. For many years before the New Deal, in an era called the "Lochner era" after the infamous case Lochner v. New York ${ }^{10}$, the Supreme Court recognized a constitutional right to freedom of contract, which prevented Congress and the states from engaging in many kinds of commercial regulation. Throughout that era, however, the Court allowed an exception to the freedom of contract for the regulation of rates in a small set of markets, permitting price-setting for businesses that were "impressed with a public interest." And one of the markets that legislatures were allowed to regulate was insurance. ${ }^{3}$ According to the Court, insurance rates could be regulated because insurance pools serve the important public function of forcing individuals to share each other's costs from catastrophic loss like fire damage. In its reasoning, the Court explicitly analogized insurance to taxation, noting that tax pools serve the similar public function of forcing individuals to share each other's costs, for public goods like national defense. $^{3}$

If that logic were still good law today (it's not, see below), the Court could have analogized mandatory insurance contributions to mandatory tax contributions, upholding the mandate itself (not the penalty for failure to comply 
with the mandate) as a functional equivalent to a tax. (Admittedly, this holding would have required a new and creative reading of Congress's taxing power. The Lochner-era cases involved state regulation (including insurance mandates for car insurance and workers' compensation funds) under the states' broad police powers.) Under this logic, the gist of the argument would have been that health insurance merely collects and redistributes money the same way that the IRS does, and a requirement to contribute to a health insurance pool is a requirement for everyone to support the national health-care infrastructure in the same way that a requirement to pay taxes for agriculture subsidies is a requirement for everyone to support the national farming infrastructure. ${ }^{11}$

Although this kind of insurance exceptionalism was not necessary to uphold the ACA's individual mandate, it would have had one advantage over Roberts's analysis. In order to survive as a tax, the ACA's penalty for failure to buy insurance had to be quite low relative to the cost of compliance. It was important to Roberts's analysis that the maximum penalty under the individual mandate is the cost of a "Bronze Level" health insurance plan, the leastcomprehensive kind of plan available on the exchanges. Given that statutory cap, Roberts noted, it might be rational for many consumers to pay the tax rather than buying insurance, much as it might be rational for many consumers to pay the tax on cigarettes rather than investing in smoking cessation. It was this feature of the mandate that convinced Roberts that the ACA's intent, at least arguably, was to tax rather than penalize.

If, instead, the Court had viewed the contribution to private insurance as a tax in itself (and a mandatory one), then Congress could use all its usual tricks to require compliance, including criminal sanctions for tax evasion. The penalty for failure to buy insurance could be equivalently penal to the penalty for failure to pay income taxes. That is, under Roberts's analysis, future congresses might run afoul of their constitutional limits if they try to intensify the consequences for failure to buy insurance, but under the Lochner-era conception of insurance as a quasi-public tax pool, that limit might not exist.

As should be apparent, this quasi-tax argument for the mandate's constitutionality would have required the same kind of market exceptionalism as the Commerce Clause analysis that Roberts rejected. It would have required rehabilitation of Lochner-era insurance exceptionalism.

\section{Market Exceptionalism and the Constitutional System}

As legal readers will have realized, the reason for contemplating this odd and outdated quasi-tax argument is not at all to criticize the Court's opinion. It is to highlight the upside of Chief Justice Roberts's rejection of health-care exceptionalism. When it comes to market-based exceptionalism in constitutional law, we've been there, and it wasn't pretty. The old rule that the states and Congress could regulate a market's rates if the market was "impressed with a public interest" - and, more generally, the old rules for commercial regulation that the freedom of contract imposed - had the undesirable but unavoidable consequence of putting unelected, unaccountable Supreme Court justices in the 
position of deciding when economic regulation was or was not sufficiently beneficial to be justified. It was under these rules that the Supreme Court infamously deemed maximum hour laws unconstitutional for bakers ${ }^{10}$ - but constitutionally permissible for miners and smelters. ${ }^{12}$ It was under these rules that the Supreme Court allowed maximum hour laws for women ${ }^{13}$ - until the justices decided that women were sufficiently empowered to exercise their own freedom of contract. ${ }^{14}$ And it was these rules, together with a couple of others, that frustrated President Franklin Roosevelt so much that he threatened to add six justices to the Supreme Court in order to create a pro-regulatory majority.

Today, the Supreme Court engages in this kind of intensive scrutiny only when Congress and the states try to regulate speech, religion, and (to a slightly lesser extent) abortion. But the Court gives Congress much more latitude to regulate commercial markets. The justices do not ask whether a particular market is a good one to regulate or whether a particular regulation is a good one to enforce. They leave those decisions to the politically accountable legislature.

If, however, Roberts had accepted the government's argument that health care is a unique market requiring unique regulation, he would have reopened the door to the kind of market exceptionalism that made such a mess in the past. As Justice Anthony Kennedy put it during oral argument, "[T]he government tells us [that it can require insurance purchases] because the insurance market is unique. And in the next case, it'll say that the next market is unique." 15

In the end, there is much to criticize in Roberts's and the dissent's Commerce Clause analyses. The distinction between regulating commerce and creating commerce seems a thin one in general, and given health insurance's direct regulatory role in altering patients' consumption incentives, the distinction seems like it should be inapplicable to the individual mandate. Furthermore, Roberts's tax analysis might leave ordinary Americans with the impression that they will be better off paying the penalty than buying insurance, an impression that Congress and President Obama actively tried to avoid by calling the provision a "mandate" and stressing the statute's penal characteristics.

Nevertheless, Roberts's refusal to accept the Solicitor General's assertions that health care is unique might be better than the alternative for the future of our constitutional system. Roberts avoided putting future Supreme Court justices in the position of asking whether other purchase mandates that Congress might dream up are also unique in the relevant way. Given the arguments that he was offered, Roberts's holding might be the best he could do.

And, of course, there is much to celebrate, too, for proponents of reform. Aside from a slight tweak to the Medicaid expansion, the statute survived.

1. Associated Press, The history of the US health care reform effort (June 28, 2012), online at http://www.foxnews.com/us/2012/06/27/us-health-carereform-efforts-through-history.

2. Nat'l Federation of Independent Business et al. v. Sibelius, Sec. of Health \& Human Servs., 567 U.S. (2012), at 32-33 [hereinafter Opinion]. 
http://www.supremecourt.gov/opinions/11pdf/11-393c3a2.pdf. Accessed July 13, 2012.

3. German Alliance Ins. Co. v. Kansas, 233 U.S. 389, 412-13 (1914).

4. Adkins v. Children's Hosp. of D.C., 261 U.S. 525, 546 (1923) (citing Munn v. Illinois, 94 U.S. 113 (1876)), overruled in part by West Coast Hotel Co. v. Parrish, 300 U.S. 379 (1937).

5. 42 U.S.C.A. $§ 18091(2)(F)$.

6. US Dept of Health and Human Services v Florida , No. 11-398, at 12, 1415, 44-45 [hereinafter Transcript]. http://www.supremecourt.gov/oral_arguments/argument_transcripts/11398-Tuesday.pdf . Accessed July 13, 2012.

7. Moncrieff, AR. Obamacare's (3) Day(s) in Court. Chest 2012; 141:13891392.

8. Opinion at $42-43$.

9. Id. at 48 .

10. Lochner v. New York, 198 U.S. 45 (1905).

11. Brief of Amici Curiae Jewish Alliance for Law and Social Action (JALSA), Jewish Council on Urban Affairs (JCUA), Jewish Social Policy Action Network (JSPAN), New England Jewish Labor Committee (JLC), and Professor Abigail R. Moncrieff in Support of Petitioners on the Individual Liberty Implications of the Minimum Coverage Provision, Dep't of Health \& Human Servs. v. Florida, No. 11-398 (U.S. Jan. 13, 2012). http://acalitigation.wikispaces.com/file/view/Jewish+Alliance+amicus+\%2811398\%29.pdf. Accessed July 13, 2012.

12. Holden v. Hardy, 169 U.S. 366 (1898).

13. Muller v. Oregon, 208 U.S. 412 (1908).

14. Adkins v. Children's Hosp. of D.C., 261 U.S. 525 (1923).

15. Transcript at 104. 